\title{
INFLUENCE OF DIFFERENT AIRFLOWS AND THE PRESENCE OF BULKING AGENT ON BIODRYING OF GARDENING WASTES IN REACTORS
}

\author{
Francisco J. COLOMER MENDOZA ${ }^{1,3 *}$, Fabián ROBLES MARTÍNEZ ${ }^{2,3}$, Ana Belem PIÑA GUZMÁN²,3, \\ Pablo VICENTE MONSERRAT ${ }^{1}$ y Antonio GALLARDO IZQUIERDO ${ }^{1,3}$
}

${ }^{1}$ Departamento Ingeniería Mecánica y Construcción. Universidad Jaume I. Avda. Vicent Sos Baynat s/n, Castellón, C.P. 12071 (España), Tel.: +34 964728111

${ }^{2}$ Unidad Profesional Interdisciplinaria de Biotecnología. Instituto Politécnico Nacional. México D.F.

${ }^{3}$ REDISA, Red de Ingeniería en Saneamiento Ambiental, http://www.redisa.net/index.html

*Autor para correspondencia: fcolomer@uji.es

(Recibido octubre 2014; aceptado mayo 2015)

Palabras clave: biorresiduo, estabilización, fermentación aeróbica, material texturizante

\section{RESUMEN}

El biosecado consiste en evaporar el agua de un sustrato biodegradable mediante el calor generado en la fermentación aerobia. Para conseguir una biomasa con baja humedad a partir de los residuos de jardinería de un campus universitario, se ha aplicado este proceso de secado biológico a dichos residuos. Por otra parte, se quiere analizar la influencia que tiene la adición de un agente texturizante en el proceso. El biosecado de este sustrato se realiza en 10 reactores con caudal de aire conocido entre 0.88 y $6.42 \mathrm{~L} / \mathrm{min} \bullet \mathrm{kg}(\mathrm{d} / \mathrm{w})$. Al sustrato de cinco reactores se añadió un $15 \%$ de material texturizante (MT), y los otros cinco solo con césped. Los parámetros que influyeron en el proceso fueron: aireación, temperatura y humedad inicial del biorresiduo. Los resultados obtenidos indicaron que los ensayos con MT presentaron una mayor reducción de humedad; después de 20 días el contenido en agua se redujo entre un 50 y un $69 \%$, permitiendo la producción de un combustible biomásico con un poder calorífico inferior (PCI) de entre $11063-13709 \mathrm{~kJ} \mathrm{~kg}^{-1}$. Después de la experiencia se concluyó también con que el MT mejora la reducción de humedad, la reducción de amoniaco y permite un buen desarrollo de la fase termofílica. Sin embargo, el aumento del caudal de aire proporcionado al reactor no es linealmente proporcional a la pérdida de peso del sustrato.

Key words: biowaste, stabilization, aerobic fermentation, bulking agent

\begin{abstract}
Biodrying consists on evaporating the water from a biodegradable substrate by the heat generated in the aerobic fermentation. To achieve a biomass with low humidity from garden waste of a university campus, this biological drying process has been applied. On the other hand, the influence of bulking agent (BA) for improving the process must be analyzed. In this work the effect of biodrying process on properties of lawn mowing and garden waste used as substrate was studied. Biodrying was performed in 10 reactors with known aeration rate from 0.88 to $6.42 \mathrm{~L} / \mathrm{min} \bullet \mathrm{kg} \mathrm{d} / \mathrm{w}$. Five reactors had $15 \%$ of bulking agent (BA) and five reactors had only grass. The parameters influencing the process were: aeration, temperature and initial moisture of biowaste. The results obtained indicate that the essays with BA presented the best reduction of moisture; after 20 days the water content of waste was reduced between 50 and $69 \%$, allowing the production of biodried waste
\end{abstract}


with a low heat value (LHV) between $11063-13709 \mathrm{~kJ} \mathrm{~kg}^{-1}$. After the experiences it is also found that the BA improves moisture reduction, drops $\mathrm{NH}_{3}$ production and permits good performance of thermophilic phase. However, the increase in aeration rate was not linearly proportional to the weight loss.

\section{INTRODUCTION}

Biodrying take advantage of strongly exothermic reactions from the biological activity, for the partial evaporation of the high humidity from the organic wastes, while preserving calorific power. The moisture content of the waste matrix is reduced through two main steps: (1) water evaporate (i.e., the change of state from liquid to gaseous occurs) from the surface of waste fragments into the surrounding air; and (2) the evaporated water is transported through the matrix by the airflow and removed with the exhaust gasses. Limited amount of free water may seep through the waste matrix and be collected at the bottom of the biodrying reactor as leachate (Velis et al. 2009).

Biodrying is a significant alternative for treating municipal solid waste (MSW) (Velis et al. 2009), mixed sludge (Navaee-Ardeh et al. 2006, 2010) and lawn mowing and garden (green) wastes (RoblesMartínez et al. 2012, Colomer-Mendoza et al. 2012a). Because of the different objectives of each process, biodrying differs from composting process but, in general terms, the former could be considered as a variation of the latter, being the main difference the sojourn time. While in a compost process the sojourn time could be three months or even more, the sojourn time in biodryng process in reactors moves from 1 to 2 weeks (Sugni et al. 2005, Velis et al. 2009, Tambone et al. 2011, Robles-Martínez et al. 2012), or 2 to 3 weeks in windrow at greenhouse conditions (Colomer-Mendoza et al. 2012a, Robles-Martínez et al. 2012, 2013).

After biodrying the refuse can be used as a source of energy, i.e., fuel (Adani et al. 2002, Sugni et al. 2005) suitable for a safe and economic combustion operation in a biomass boiler (Navaee-Ardeh et al. 2010), or as energy source via biogas production by waste re-moistening, i.e. bioreactor. Conditioning solid biomass-fuel can be reasonable both ecologically and economically (Dach and Bode 2006). These entire elements make the biodrying process more attractive compared to the conventional drying techniques because the reactor is a self-heating process.

Currently, most studies of biodrying process focus on the aerobic technology, where the presence of an adequate supply of oxygen, moisture, and aerobic bacteria, allows the hydrocarbons contained in organic wastes undergo partial oxidation to smaller molecules. This process based on the "biological oxidation" is controlled by parameters such as type of waste, microorganisms, biomass temperature, water content, aeration, $\mathrm{C} / \mathrm{N}$ ratio and presence of bulking agent (BA) and results in the reduction of water mainly as vapor by high temperatures and adequate ventilation (Zhang et al. 2008), as well as the production of $\mathrm{CO}_{2}$, destruction of odour-forming compounds $\left(\mathrm{NH}_{3}\right)$ and formation of organic material (biomass). The $\mathrm{NH}_{3}$ production depends of the $\mathrm{pH}$ of the matrix, in this way, when $\mathrm{pH}$ is acid, the volatile ammonia becomes protonated as ammonium $\left(\mathrm{NH}_{4}{ }^{+}\right)$, the non-volatile odorless salt form of the chemical (Naylor et al. 2009).

So in compost as in biodrying process, it is necessary to use BA in some cases in order to improve the process performance. Many materials have been used as BA to provide favorable free air space and regulate the moisture content; for instance, Adhikari et al. (2009) tested chopped wheat straw, chopped mature hay and pine wood shaving during food waste composting. It has been established that particle size determines the loss water velocity. A study of Raichura and McCartney (2006) on composting of municipal biosolids reports that the addition of wood chips with a small particle size of $5.2 \mathrm{~mm}$ resulted in a lower moisture loss as compared to a larger particle size of $40 \mathrm{~mm}$, because of greater resistance to ventilation. Also, Zhao et al. (2011) tested straw and sawdust in biodrying sludge and their results showed that straw has substantial biodegradation potential in the aerobic process and sawdust has poor capacity to be degraded. Bulking agents also play a significant role, as carbon source or a substrate (Vuorinen 2000), most BA in a compost process will act as a buffer against the organic acids produced during early stages of biodegradation (Haug 1993).

Biowaste with moisture below $35 \%$ on a wet weigh basis, will be biologically dormant and consequently, its respiration index will be falsely low (Barrena et al. 2006). Therefore, to maintain the growing and activity of microorganisms it is necessary to add water above all in compost process (Liang et al. 2003, Tremier et al. 2005, Wagland et al. 2009) 
but sometimes, water is added during biodrying process in order to promote the aerobic fermentation, in hydrolytic stage by means of the recirculation of a part of the leachate generated (Zhang et al. 2009).

Thus, there have been several researches about variations in the above parameters to see how they affect the process of biodrying. Adani et al. (2002) in their investigations with MSW carried out three trials at three different biomass temperatures, obtained by airflow rate control, concluding that biodegradation and biodrying were inversely correlated: fast biodrying produced low biological stability and vice versa. The results of investigations of Sugni et al. (2005) with MSW suggested that the daily inversion of airflow in biodrying by means of reactors eliminates marked temperature differences and leads to a homogeneous final product. The study of Zhao et al. (2011) aimed at investigating the interactive influence of airflow rate and turning frequency on water removal and biomass energy utilization for dewatered sludges. Finally, a novel continuous biodrying process carried out by Navaee-Ardeh et al. (2010) was developed in order to increase the dry solids content of the sludge to economic levels rendering it suitable for a safe and economic combustion operation in a biomass boiler. In most cases MSW is the main substratum studied for biodrying.

The aim of this work was to evaluate and compare the different reductions of moisture according to the airflow supplied in different bioreactors with grass as a substratum. Moreover, the effectiveness of pruning wastes or wood shavings as BA on the biodrying process have been studied. Relation between moisture reduction, temperature behavior, and $\mathrm{CO}_{2}$ and $\mathrm{NH}_{3}$ production was analyzed.

\section{MATERIALS AND METHODS}

The experimental research was performed by using 10 experimental reactors $(25 \mathrm{~L})$ which were fed with gardening wastes as biomass. In a yearly characterization of gardening waste from the campus, a $15 \%$ of woody part is obtained. Therefore biodrying reactors were organized in two sets: In set 1, five reactors were filled with $7 \mathrm{~kg}$ of grass (lawn) and were operated with different airflow ranging from 2 to 10 $\mathrm{L} / \mathrm{min}$. In set 2 , five reactors were filled with $7 \mathrm{~kg}$ of grass and $15 \%$ of BA (pruning waste and wood shavings with particle size between 2 and $3 \mathrm{~cm}$, and initial moisture of $4.33 \%$ ) and operated at the same air flow that Set 1 . The airflow into the reactors had a temperature $22-24{ }^{\circ} \mathrm{C}$ and relative humidity $55-75 \%$ according the parameters of the laboratory room. Wastes were directly collected from the gardens on Universidad Jaume I (Castellón, Spain). The biodrying reactors were designed and built with cylindrical plastic drums of $40 \mathrm{~cm}$ diameter and $62 \mathrm{~cm}$ high with fiberglass insulation around the perimeter and on top. They have been installed inside a closed room heated to $25^{\circ} \mathrm{C}$ and $70 \%$ relative humidity. Five different aeration rates $(1.28$ a $6.42 \mathrm{~L} / \mathrm{min} \bullet \mathrm{kg} \mathrm{d} / \mathrm{w}$ grass and $0.88 \mathrm{a} 4.38 \mathrm{~L} / \mathrm{min} \bullet \mathrm{kg} \mathrm{d} / \mathrm{w}$ grass $+\mathrm{BA}$ ) were supplied by forced air driving the air through the reactor by means of four blowers on the bottom of the reactor (Table 1). In all assays, the waste residence time in the reactor was 20 days. Leachate generated daily was collected by an outlet (open-close) at the bottom of reactors and quantified (Fig. 1).

Each reactor has a capacity of 25 liters, divided into two compartments; the lower is occupied by 4 diffusers. A horizontal metal grid separates the lower

TABLE I. OPERATIONAL CONDITIONS OF BIODRYING REACTORS

\begin{tabular}{|c|c|c|c|c|c|}
\hline & Reactor & Biowaste & $\begin{array}{c}\text { Initial moisture } \\
(\%)\end{array}$ & Airflow (L/min) & $\begin{array}{c}\text { Airflow }(\mathrm{L} / \mathrm{min} \cdot \mathrm{kg} \\
\mathrm{d} / \mathrm{w})\end{array}$ \\
\hline \multirow{5}{*}{ Set 1} & 1 & Grass & 77.73 & 2 & 1.28 \\
\hline & 2 & Grass & 77.73 & 4 & 2.57 \\
\hline & 3 & Grass & 77.73 & 6 & 3.85 \\
\hline & 4 & Grass & 77.73 & 8 & 5.13 \\
\hline & 5 & Grass & 77.73 & 10 & 6.42 \\
\hline \multirow{5}{*}{ Set 2} & 6 & Grass $(85 \%)+\mathrm{BA}(15 \%)$ & 67.35 & 2 & 0.88 \\
\hline & 7 & Grass $(85 \%)+$ BA $(15 \%)$ & 67.35 & 4 & 1.75 \\
\hline & 8 & Grass $(85 \%)+\mathrm{BA}(15 \%)$ & 67.35 & 6 & 2.63 \\
\hline & 9 & Grass $(85 \%)+$ BA $(15 \%)$ & 67.35 & 8 & 3.50 \\
\hline & 10 & Grass $(85 \%)+\mathrm{BA}(15 \%)$ & 67.35 & 10 & 4.38 \\
\hline
\end{tabular}




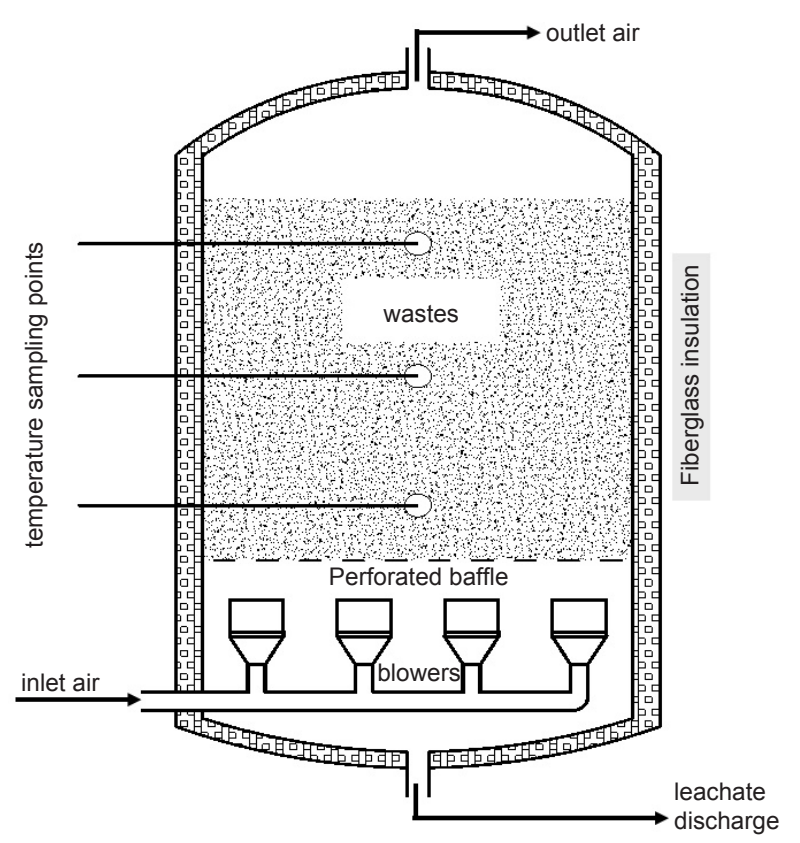

Fig. 1. Scheme of the reactors

and the upper part and retains the waste mass. In the loaded reactors injection airflow was supplied for 20 days. During this period, the following parameters were measured:

- $\mathrm{pH}$ and volume of leachates

- Weight loss using a portable scale which is directly related to the loss of moisture from the sample.

- Temperature in the mass of waste (3 times/day in 3 points) by means of compost probe Leybold Didactic Gmbh model 666210.

- Reactor outlet gases (12 hours after the beginning of the experience, 2 times/day): $\mathrm{CH}_{4}, \mathrm{CO}_{2}$, $\mathrm{O}_{2}, \mathrm{SO}_{2}$ and $\mathrm{NH}_{3}$ by means of portable analyzer Dräger model SEP 8314060.

When the dwell time finished (20 days) representative samples were taken in order to be analyzed. The samples were dried in an oven $\left(105^{\circ} \mathrm{C}, 24\right.$ hours $)$, in order to determine their moisture content following the ISO 5068-1 standard. Dried waste was ground in a mill so that $98.75 \%$ of the particles could pass through a $2 \mathrm{~mm}$ sieve. In each of the samples, the heating value was determined by means of a PARR 1261 Bomb Calorimeter ${ }^{\circledR}$ device, in accordance with ISO 1928:1995. Nitrogen content was analyzed using thermal conductivity equipment (LECO FP$528 \AA)$, carbon and sulfur were measured by infrared spectrometry equipment (LECO SC 144 DR $®$ ) and hydrogen content was determined by means of atomic mass spectrometry equipment. Carbon, sulfur and nitrogen content would allow emissions in the incineration process to be estimated in order to prevent the need for process air or off-gas treatment line. Ash was determined following ISO 1171:1997 specifications. The data shown are the average of four analyses.

\section{RESULTS AND DISCUSSIONS}

In this section, a process system analysis is performed to identify key variable(s) in the biodrying reactor, and then the impact of the key variable(s) is discussed on the overall performance of the biodrying reactor.

\section{Leachate generation}

Only reactors with the minor air flow rate (2 and $4 \mathrm{~L} / \mathrm{min}$ ) generated leachate during the first week of biodrying. Reactors without BA produced $133 \mathrm{~mL}$ (Reactor 1) and $103 \mathrm{~mL}$ (Reactor 2), while reactors with BA produced $150 \mathrm{~mL}$ (Reactor 6) and $10 \mathrm{~mL}$ (Reactor 7); which corresponds to 0.21 to $3.18 \%$ of initial moisture (Table 2). An important portion of the rest of the water was removed by the combined action of aeration flow and the heat generated by the microorganisms present in the waste. Pruning and gardening wastes produce low volumes of leachates compared to horticultural or fruits wastes, because green wastes have lignin and cellulose in their structure. This characteristic improves the biodrying process of green wastes.

\section{Moisture reduction}

Moisture reduction depends of the airflow and the presence or not of BA. According to the moisture dynamics, a sustained moisture loss was observed in almost all the assays, although each line has a particular slope. Figure 2 shows clearly two groups: The group of five reactors without BA (1st group) started with a water content of $77.73 \%$ and at the end of the process (20 days) the moisture content decreased $18.99 \%$ (reactor 1 ), $31.75 \%$ (reactor 2), $35.01 \%$ (reactor 3 ), $38.43 \%$ (reactor 4 ) and $43.78 \%$ (reactor 5). In this group the water evaporated ranged between 51.3 and $77.8 \%$ of the initial moisture, the moisture loss was more directly influenced by the air flow rate. The group of five reactors with BA (2nd group) started with $67.35 \%$ of moisture and at the end of the biodrying, moisture content decreased $50.17 \%$ (reactor 6 ), $65.39 \%$ (reactor 7 ), $67.33 \%$ (reactor 8), $68.14 \%$ (reactor 9) and $68.94 \%$ (reactor 10). Except for the reactor $6(2 \mathrm{~L} / \mathrm{min})$, the final 
TABLE II. SUMMARY OF THE DATA OBTAINED - i: INITIAL; f: FINAL ${ }^{1}$

\begin{tabular}{|c|c|c|c|c|c|c|c|}
\hline & Reactor & Moisture $_{(\mathrm{f})}(\%)$ & Leachate (\%) & $\begin{array}{c}\text { Evaporated } \\
\text { water }(\%)\end{array}$ & $\begin{array}{l}\mathrm{C}_{(\mathrm{f})} \\
(\%)\end{array}$ & $\begin{array}{l}\mathrm{N}_{(\mathrm{f})} \\
(\%)\end{array}$ & $\mathrm{C}_{(\mathrm{f})} / \mathrm{N}_{(\mathrm{f})}$ \\
\hline & \multicolumn{4}{|c|}{ Moisture $_{(i)}=77.73 \%(1.07)$} & $\begin{array}{c}C_{(i)}=26.45 \% \\
(1.65)\end{array}$ & $\begin{array}{c}N_{(i)}=3.99 \% \\
(1.01)\end{array}$ & $\begin{array}{c}C_{(i)} / N_{(i)}= \\
6.63\end{array}$ \\
\hline \multirow{6}{*}{$\begin{array}{c}\text { Set } 1 \\
\text { (Without BA) }\end{array}$} & 1 & $62.97(1.05)$ & 2.39 & 51.29 & $28.32(0.55)$ & $3.90(0.22)$ & 7.26 \\
\hline & 2 & $53.05(0.96)$ & 1.89 & 67.65 & $26.01(0.42)$ & $3.45(0.12)$ & 7.54 \\
\hline & 3 & $50.51(0.95)$ & 0 & 70.77 & $27.53(0.05)$ & $3.63(0.04)$ & 7.58 \\
\hline & 4 & $47.86(0.88)$ & 0 & 73.71 & $26.09(0.31)$ & $3.70(0.88)$ & 7.05 \\
\hline & 5 & $43.70(0.89)$ & 0 & 77.76 & $26.36(0.12)$ & $2.07(0.19)$ & 12.73 \\
\hline & \multicolumn{4}{|c|}{ Moisture $_{(i)}=67.35 \%$} & $\begin{array}{c}C_{(i)}=25.02 \% \\
(1.88)\end{array}$ & $N_{(i)}=2.84 \%$ & $\begin{array}{c}C_{(i)} / N_{(i)}= \\
8.81\end{array}$ \\
\hline \multirow{5}{*}{$\begin{array}{c}\text { Set } 2 \\
\text { (With BA) }\end{array}$} & 6 & $33.56(1.45)$ & 3.18 & 75.58 & 28.17 (1.02) & $2.26(0.45)$ & 12.46 \\
\hline & 7 & $23.31(0.68)$ & 0.21 & 85.35 & $28.63(1.22)$ & $2.43(0.01)$ & 11.78 \\
\hline & 8 & $22.00(0.98)$ & 0 & 86.41 & $28.06(1.38)$ & $2.57(0.32)$ & 10.92 \\
\hline & 9 & $21.46(1.55)$ & 0 & 86.84 & $26.44(1.21)$ & $1.82(1.32)$ & 14.52 \\
\hline & 10 & $20.92(1.02)$ & 0 & 87.26 & $28.43(0.87)$ & $2.00(1.08)$ & 14.22 \\
\hline
\end{tabular}

1 (value in brackets: standard deviation)

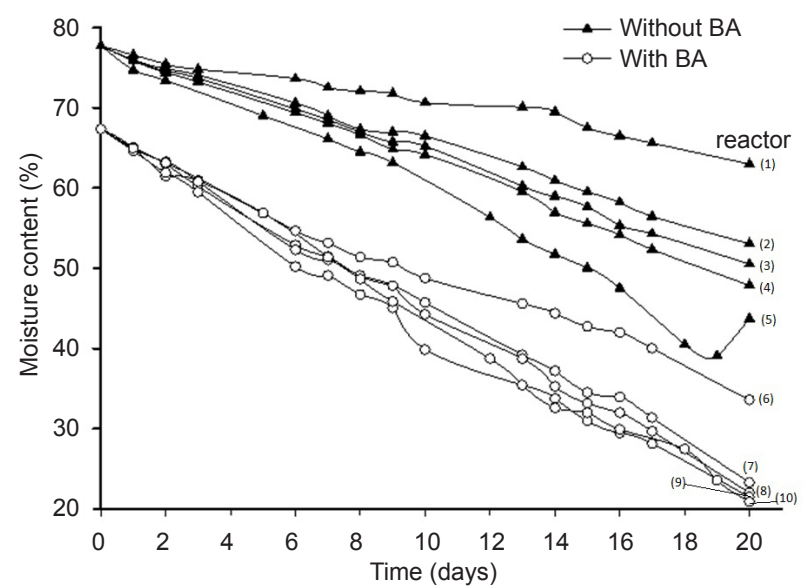

Fig. 2 Moisture content in reactor with and without bulking agent

moisture content in reactors with BA ranged between 20 and $25 \%$ after twenty days of biodrying. The effect of BA on biodrying has also been reported by some authors, eg. Frei et al. (2004) used purchased bark (water content about 40-50\%) to biodry sewage sludge. Choi et al. (2001) and Zhao et al. (2011) used sawdust and/or straw (water content about 9-11\%). In any case, bulking agent is used to promote the airflow through the wastes and facilitate the aerobic fermentation both in biodrying and composting (Robles-Martínez et al. 2010, Colomer-Mendoza et al. 2012b).

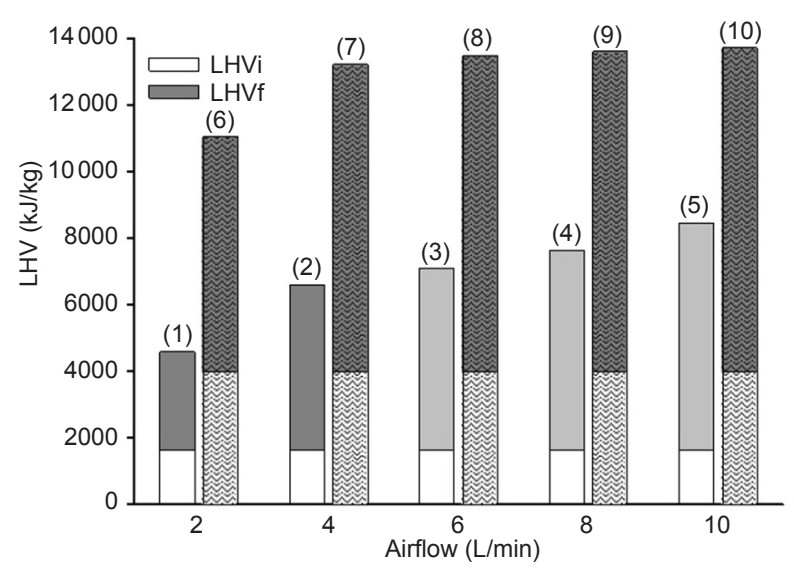

Fig. 3 Increase in LHV after biodrying process in reactors. $\square$ Reactors without BA. 挋 Reactors with BA

Therefore it could be proposed that the gradual increase in the air flow rate between 4 until $10 \mathrm{~L} / \mathrm{min}$ has not an important effect in moisture loss, the air flow rate increases are not proportional to the decrease in moisture (Fig. 3) which involves that heat generated in fermentation has influence in biodrying. This influence of fermentation is even more evident in the reactors with BA, since with aeration rates above $2.5 \mathrm{~L} / \mathrm{min} \mathrm{kg} \mathrm{d} / \mathrm{w}$, final moisture is quite similar after 20 days. In this case the water evaporated ranged between 75.6 and $87.3 \%$ of the initial content, it was superior to reactors without BA. 
In their works, Velis et al. (2009) reported that commercial process cycles are completed within $7-15$ days, with mostly loses of water $25-30 \% \mathrm{w} / \mathrm{w}$, leading to low moisture contents $(<20 \% \mathrm{w} / \mathrm{w})$. Adani et al. (2002) and Tambone et al. (2011) achieved a reduction of water content of MSW by $66.7 \%$ and $65.5 \%$ in 9 and 14 days, respectively. Shao et al. (2010) were able to reduce the water content from $73.0 \%$ to $48.3 \%$ in 16 days. In comparison with these authors, in this study the reactors with BA allowed to reach a moisture content between 30 and $42 \% \mathrm{w} / \mathrm{w}$ in 15 days. The lowest moisture ( $30 \%$ ) was obtained in the reactor with an air flow rate of $8 \mathrm{~L} / \mathrm{min}$.

According with Barrena et al. (2006), in a biodrying reactor, when the moisture content of the biomass decrease to $35 \%$, the microbial activity drastically slows down, but it is not inhibited. Therefore, below $35 \%$ of moisture air convection is the main mechanism of drying to $25 \%$ or less of water content. Sugni et al. (2005) couldn't diminish water content more than $53.5 \%$ in 10 days by means of inverting air flow in order to homogenize the substrate. In this paper, the first part of the biodrying (moisture from 75 to $35 \%$ ) is probably provoked mainly by aerobic fermentation, since with this moisture the growing of microorganisms is feasible. Moisture content below $35 \%$ only was reached in four reactors with $\mathrm{BA}(7,8$, 9,10 ) between 13 and 15 days. Reactor 6 reached this level in day 20. After this period of time, the airflow was the main drying mechanism. In reactor without BA, water content was superior to $40 \%$ after 20 days, this situation allows the microorganisms degrading organic matter, and therefore it is expected that the LHV be lesser and the biodrying process will be longer than the typical process time in reactors $(7-15$ days) as reported by Velis et al. (2009).

\section{Lower heating value (LHV)}

In order to assess the use of this waste as a biomass fuel, the initial and final LHV were analyzed; obviously, the lesser the moisture of waste, the higher the LHV is. In reactor 5 the increase of LHV of the biodried waste reached $419.73 \%$, which involves 8457 $\mathrm{kJ} / \mathrm{kg} \mathrm{w} / \mathrm{w}$. Reactor 10 had 13,709 kJ/kg, nevertheless the increase has been smaller, $243.5 \%$. Samples of mixture of grass and BA had a bigger value of initial LHV $(3,990.90 \mathrm{~kJ} / \mathrm{kg})$ than grass alone $(1627.19$ $\mathrm{kJ} / \mathrm{kg}$ ). It could be explained by the superior LHV of pruning waste and wood saving and because of the initial moisture was lower in reactors with BA than in reactors without BA. It is important to understand that the final values of LHV for biodried material, higher than the initial LHV of MSW, are not related to energy generation but to its concentration in a lower mass.

The reached moisture level in the waste after the biodrying process was reasonably low in reactors with BA. Considering that in an incineration plant a LHV between $8500-10000 \mathrm{~kJ} / \mathrm{kg}$ is recommended, the biodried gardening waste using BA could be used for energy recovery as a refuse derived fuel (RDF) in an incineration plant because of their LHV reached in this work (11063-13 709 kJ/kg). Although the European Association of Waste Treatment Companies for Stabilized Wastes (EURITS) establish a LHV > $15000 \mathrm{~kJ} / \mathrm{kg} \mathrm{w} / \mathrm{w}$ on the basis of RDF quality standard. The values presented in this work are similar to other works as dried MSW: about $8200-13813 \mathrm{~kJ} /$ $\mathrm{kg}$ (Zhang et al., 2009, Sugni et al., 2005) or about $14700-18800 \mathrm{~kJ} / \mathrm{kg}$ (Tambone et al. 2011). Shao et al. (2010) increase the LHV of his MSW from 4010 to $10300 \mathrm{~kJ} / \mathrm{kg}$. Other types of waste with a high initial moisture as sewage sludge had a much bigger increase in LHV eg. from 500 to $6000 \mathrm{~kJ} / \mathrm{kg}$ after the biodrying process (Stasta et al. 2006). Nevertheless, gardening wastes have not the same high LHV than MSW containing plastics, paper and cardboard inside the mixture $(14500 \mathrm{~kJ} / \mathrm{kg})$, because their content on chlorine is much less (Velis et al. 2012). According to published data, Velis et al. (2010) studied quality of management initiatives for RDF, as well as, quality of mechanical-biological treatment (MBT) plants.

\section{Temperature evolution}

The evolution of the temperature within the waste mass has followed a behavior quite similar in the five reactors with grass (without BA), with a significant increase during the first week, reaching the thermophilic phase $\left(>40{ }^{\circ} \mathrm{C}\right)$ in four reactors and only at $35^{\circ} \mathrm{C}$ in the reactor 5 (with the highest airflow); after $7-8^{\text {th }}$ day temperature decreased in all reactors. In reactors with $\mathrm{BA}$ values of temperature were quite similar, even surpassing previous values $\left(52^{\circ} \mathrm{C}\right)$.

Velis et al. (2009) reported that a mechanically supported aeration of waste is critical for biodrying because it provides a mass and energy flow media, enabling: 1) water content removal; 2) heat transfer redistribution, removing excessive heat and adjusting the matrix temperature; and 3) $\mathrm{O}_{2}$ to meet the stochiometric demand for aerobic decomposition. However, the results of this work show that even if with high airflow waste can achieve a good dryness, the impact of a high airflow may be negative, because it takes away the heat affecting the thermophilic phase (Fig. 4). 

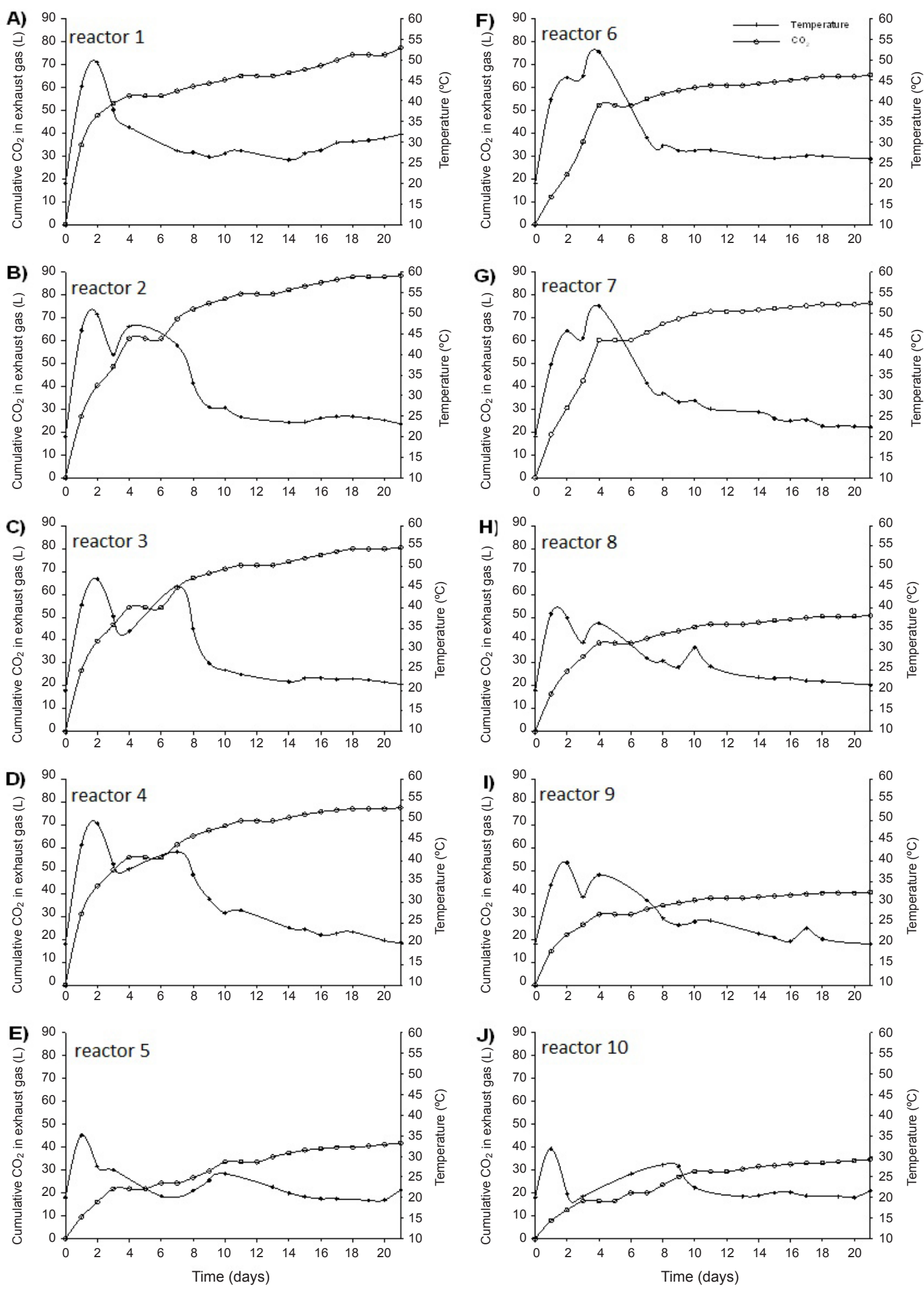

Fig. 4. Temperature behavior and cumulative $\mathrm{CO}_{2}$ production in the exhaust gas (reactors $1,2,3$, 4 and 5, with grass and reactors $6,7,8$, 9 and 10 with grass + BA) 
On the other hand, the increase of temperature $\left(>50{ }^{\circ} \mathrm{C}\right)$ caused by aerobic fermentation and air treatment reduces the strong odors, and has been proposed as a means of reducing, and even eliminating pathogens present in the livestock waste (Collick et al. 2007) and, in some cases, to remove volatile organic compounds (He et al. 2010) and other pollutants in the air emissions (Ragazzi et al. 2011).

Comparing temperatures attaint in both sets of reactors it was found that the highest temperatures recorded during the process $\left(52^{\circ} \mathrm{C}\right)$ were obtained for reactors with BA with the lower flow rates (2 and $4 \mathrm{l} / \mathrm{min}$ ). Therefore it could be assumed that partial sanitization of the biodried waste was also accomplished.

\section{Exhaust gas composition}

In Figure 4 the $\mathrm{CO}_{2}$ concentration in exhaust gas and temperature behavior in the reactors with and without $\mathrm{BA}$ are showed. In all the cases the $\mathrm{CO}_{2}$ production had the same behavior that the temperature. At the beginning of the biodrying process, the production of $\mathrm{CO}_{2}$ showed an exponential increase corresponding to a rapid raise of temperature during the thermophilic phase, as a result of an exponential growth and activity of microorganisms. The $\mathrm{CO}_{2}$ production during the days 5 to 7 days was intensive in all the reactors. Nevertheless, this proportion was diminishing according to the days passed, reaching values between 0.03 and $0.78 \%$ at the end of the process.

As reported by Amlinger and Peyr (2008), a mismanagement of the system, such as the use of an unbalanced initial mixture of source materials, excessive moisture or insufficient aeration, produce more $\mathrm{CO}_{2}$ that one system well operated. Agreed with these authors, in this study, the reactors with BA and lower air flow rate (ie. excessive moisture and insufficient aeration) produced higher $\mathrm{CO}_{2}$ volume than reactors without BA (reactors 1 and 2) even if the airflow may be low ( 2 and $4 \mathrm{~L} / \mathrm{min}$ ). In this case, the presence of BA improved the porosity of matrix diminishing the resistance to air flow and enabling the water content removal and heat transfer redistribution through the matrix. It represents an advantage because a minimal biodegradation occurred resulting in a better preserved calorific value of the organic chemical compounds of waste.

$\mathrm{CO}_{2}$ and $\mathrm{NH}_{3}$ are products of waste decomposition. $\mathrm{NH}_{3}$ concentration was irregular (Fig. 5), reaching values of $141 \mathrm{ppm}$ in reactor $1,126 \mathrm{ppm}$ in reactor $2,200 \mathrm{ppm}$ in reactor $3,197 \mathrm{ppm}$ in reactor $4,15 \mathrm{ppm}$ in reactor $5,14 \mathrm{ppm}$ in reactor $6,17 \mathrm{ppm}$ in reactor $7,23 \mathrm{ppm}$ in reactor $8,14 \mathrm{ppm}$ in reactor 9 and $39 \mathrm{ppm}$ in reactor 10 . These high concentrations were obtained at the same period of time when $\mathrm{CO}_{2}$ production was intensive and the temperature was in the thermophilic phase ( $2^{\text {nd }}$ to $5^{\text {th }}$ day).

Reactors without BA produce ten times as much $\mathrm{NH}_{3}$ as reactor with BA (Fig. 5). This phenomenon was observed in a composting process studied by Tiquia and Tam (2000), which reported that the addition of bulking agent reduced the loss of $\mathrm{NH}_{3}$. These values were very low, probably promoted by higher aeration of the mixture.

In some works (Amlinger and Peyr 2008) it has been reported that in aerobic processes like composting and $\mathrm{MBT}, \mathrm{NH}_{3}$ concentrations are highest at temperatures above $40-50{ }^{\circ} \mathrm{C}$. Pagans et al. (2006) reported that temperature seems to be the most suitable parameter to control ammonia emissions. In the case of biodrying process, the period of time sustaining temperatures higher than $40^{\circ} \mathrm{C}$ are very short in relation to the compost process, so the $\mathrm{NH}_{3}$ emissions will be lower in the first case. There is also the possibility of $\mathrm{N}_{2} \mathrm{O}$ emissions; however in this work this compound was not measured.

Finally, $\mathrm{O}_{2}$ concentration in the exhaust gas had an opposite behavior to $\mathrm{CO}_{2}$ because it was increasing as the days passed (data do not shown). In both groups, $\mathrm{CH}_{4}$ concentration in exhaust gases was nil in all cases, which involves an aerobic fermentation.

\section{C/N Ratio}

It has been reported the $\mathrm{C} / \mathrm{N}$ ratio as one of the most influential experimental parameters in the batch biodrying process (Roy et al. 2006). Typical values of $\mathrm{C} / \mathrm{N}$ ratio for the biodrying and composting process range between 15 and 30 (Haug 1993, Navaee-Ardeh et al. 2010). A low $\mathrm{C} / \mathrm{N}$ ratio would ordinarily result

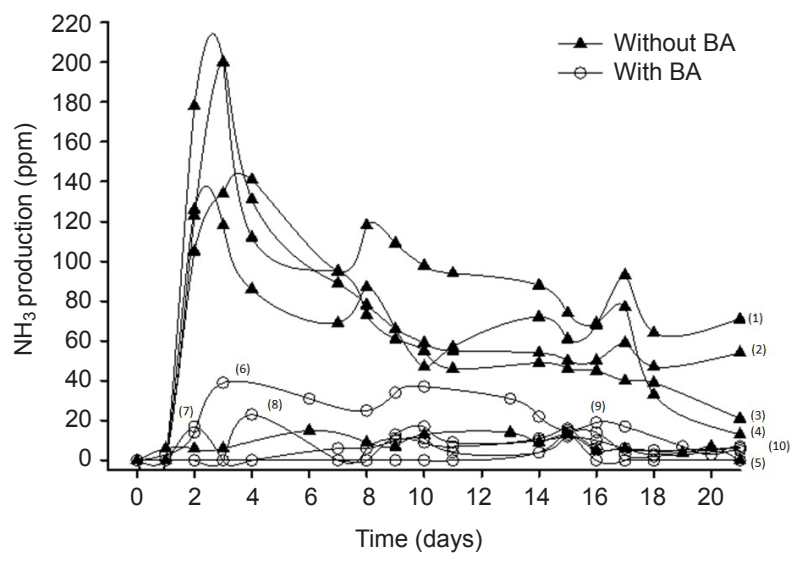

Fig. 5. $\mathrm{NH}_{3}$ concentration (ppm) in the exhaust gas in reactors with grass and reactors with grass + BA. 
in voluminous losses of ammonia gas because of excess of nitrogen relative to biodegradable carbon in the mix. In this study, the initial $\mathrm{C} / \mathrm{N}$ ratio in all the experiments was low in both with BA $(6.69 \%)$ and without BA $(8.81 \%)$; thus, the tested material was very rich in nitrogen. However, the biodrying process was achieved, reducing the moisture content near $70 \%$. Therefore, such biomass tended to release some of the excess nitrogen as ammonia during the biodrying process.

According to the previous data, biodrying of gardening wastes results a useful way to diminish moisture and weight. In fact, after 20 days, the biowaste is stabilized and moisture reaches nearly $20 \%$ is some cases, which permits that the waste can be used as a biomass fuel.

\section{CONCLUSIONS}

In this work gardening wastes were biodried in reactors during 20 days resulting in a decrease of the water content of $50-69 \%$ when the biomass was mixed with bulking agent, even if the percentage added was low $(15 \%)$ and the process was enhanced by the forced aeration. Indeed, the higher the air flow rate, the higher the moisture loss was, although this relationship was not linear. Therefore the influence of the heat generated in the aerobic fermentation is demonstrated.

The significant moisture loss (more than $50 \%$ in the reactors with BA), as well as the high values of LHV reached in this work suggest that biodrying process could be a good and interesting solution for gardening waste management in terms of stabilizing it, reduction of transport cost and would allow the production of a refused derived fuel with promising energy content.

\section{ACKNOWLEDGEMENTS}

The authors are grateful to the Spanish Ministry of Science and Innovation for funding for this study (Project ACI2009-0993) in the program "Convocatoria de Ayudas del Programa Nacional de Internacionalización de la I+D. Subprograma de Fomento de la Cooperación Científica Internacional (ACIPROMOCIONA)".

\section{REFERENCES}

Adani F., Baido D., Calcaterra E. y Genevini P. (2002). The influence of biomass temperature on biostabiliza- tion-biodrying of municipal solid waste. Bioresource Technol. 83, 173-179. http://dx.doi.org/10.1016/ S0960-8524(01)00231-0

Adhikari B.K., Barrington S., Martínez J. y King S. (2009). Effectiveness of three bulking agents for food waste composting. Waste Manage. 29, 197-203. http://dx.doi. org/10.1016/j.wasman.2008.04.001

Amlinger F., Peyr S. y Cuhls C. (2008). Green house gas emissions from composting and mechanical biological treatment. Waste Manage. Res. 26, 47-60. DOI: $10.1177 / 0734242 X 07088432$

Barrena R., Vázquez F. y Sánchez A. (2006). The use of respiration indices in the composting process: a review. Waste Manage. Res. 24(1), 37-47. DOI: $10.1177 / 0734242 X 06062385$

Choi H.L., Richard T.L. y Ahn H.K. (2001). Composting high moisture materials: Biodrying poultry manure in a sequentially fed reactor. Compost Sci. Utilization 9, 303-311. http://dx.doi.org/10.1080/106565 7X.2001.10702049

Collick A.S., Inglish S., Wright P., Steenhuis T.S. y Bowman D.D. (2007). Inactivation of Ascaris suum in a biodrying compost system. J. Environ. Qual. 36, 1528-1533. DOI: $10.2134 /$ jeq2006.0523

Colomer-Mendoza F.J., Robles-Martínez F., Herrera-Prats L., Gallardo-Izquierdo A. y Bovea M.D. (2012a). Biodrying as a biological process to diminish moisture of gardening and harvest wastes. Environment, Development and Sustainability 14, 1013-1026.

DOI: $10.1007 / \mathrm{s} 10668-012-9369-1$

Colomer-Mendoza F.J., Herrera-Prats L., Robles-Martínez F., Gallardo-Izquierdo A. y Carlos Alberola M. (2012b). Secado de residuos de jardinería en reactores mediante procesos biológicos. Rev. Int. Contam. Ambie. 28(1), 59-65.

Dach J. y Bode S. (2006). Biological drying of biowaste to generate biomass. In: ORBIT 2006, 5th International Conference. Biological Waste Management, from Local to Global. 13th a 15th of September 2006, Weimar, Germany. 859-866.

Frei K.M., Stuart P.R. y Cameron D. (2004). Novel drying process using forced aeration through a porous biomass matrix. Dry. Technol. 22, 1191-1215. http:// dx.doi.org/10.1081/DRT-120038587

Haug R.T. (1993). The practical handbook of compost engineering. CRC Publishers Ltd., Boca Raton, Florida, USA.

He P., Tang J., Zhang D., Zeng Y. y Shao L. (2010). Release of volatile organic compounds during bio-drying of municipal solid waste. J. Environ. Sci. 22(5), 725-759. DOI: 10.1016/S1001-0742(09)60173-X

Liang C., Das K.C. y McClendon R.W. (2003). The influence of temperature and moisture contents regimes on the aerobic microbial activity of biosolids composting 
blend. Bioresource Technol. 86(2), 131-137. http:// dx.doi.org/10.1016/S0960-8524(02)00153-0

Navaee-Ardeh S., Bertrand F. y Stuar P.R. (2006). Emerging Biodrying Technology for the Drying of Pulp and Paper Mixed Sludges. Dry. Technol. 24, 863-878. http://dx.doi.org/10.1080/07373930600734026

Navaee-Ardeh S., Bertrand F. y Stuar P.R. (2010). Key variables analysis of a novel continuous biodrying process for drying mixed sludge. Bioresource Technol. 101, 3379-3387. http://dx.doi.org/10.1016/j. biortech.2009.12.037

Naylor L., Nicoletti R. y Calderiso M. (2009). Amendment Free, Mechanically Enhanced Biodrying Composting of Dewatered Undigested Sewage Sludge: USCC (U.S. Composting Council), 17th Annual Conference. Houston, TX USA 26-29 January 2009. Massachusetts: Siemens Water Technologies. http://www.compostingcouncil.org/wp/wp-content/uploads/2013/02/ Nicoletti.pdf

Pagans E, Barrena R., Font X. y Sánchez A. (2006). Ammonia emissions from the composting of different organic wastes. Dependency on the process temperature. Chemosphere 62, 1534-1542. http://dx.doi. org/10.1016/j.chemosphere.2005.06.044

Ragazzi M., Rada E.C. y Antolini D. (2011). Material and energy recovery in integrated waste management systems: an innovative approach for the characterization of the gaseous emissions from residual MSW biodrying. Waste Manage. 31(9-10), 2085-2091. http:// dx.doi.org/10.1016/j.wasman.2011.02.024

Raichura A. y McCartney D. (2006). Composting of municipal biosolids: effect of bulking agent particle size on operating performance. J. Environ. Eng. Sci. 5, 235-241 DOI: 10.1139/s06-004

Robles-Martínez F., Ramírez-Sánchez I.M., Piña-Guzmán A.B. y Colomer-Mendoza F.J. (2010). Efecto de la adición de agentes estructurantes a residuos hortícolas en tratamientos aerobios. Ingeniería Agrícola y Biosistemas 2(1), 44-51.

DOI: $10.5154 /$ r.inagbi.2010.08.010

Robles-Martínez F., Silva-Rodríguez E.M., EspinosaSolares T., Piña-Guzmán A.B., Calixto-Mosqueda C., Colomer-Mendoza F.J. y Durán-Páramo E. (2012). Biodrying under Greenhouse Conditions as Pretreatment for Horticultural Waste. Journal of Environmental Protection 3(4), 298-303. DOI:10.4236/jep.2012.34038

Robles-Martínez F., Gerardo-Nieto O., Piña-Guzmán A.B., Montiel Frausto L., Colomer-Mendoza F.J. y Orozco Álvarez C. (2013) Obtención de un combustible alterno a partir del biosecado de residuos hortofrutícolas. Rev. Int. de Contam. Ambie. 29(3), 79-88. http://www.at- mosfera.unam.mx/editorial/rica/acervo/29_sup_3/14Fabian_Robles_FINAL.pdf

Roy G., Jasmín S. y Stuart P.R. (2006). Technical modelling of a batch biodrying reactor for pulp and paper mill sludge. 17th CHISA International Congress of Chemical and Process Engineering. Prague, Czech Republic.

Shao L.M., Ma Z.H., Zhang H., Zhang D.Q. y He P.H. (2010). Bio-drying and size sorting of municipal solid waste with high water content for improving energy recovery. Waste Manage. 30, 1165-1170. http://dx.doi. org/10.1016/j.wasman.2010.01.011

Stasta P., Boran J., Bebar L., Stehlik P. y Oral J. (2006). Thermal processing of sewage sludge. Appl. Therm. Eng. 26, 1420-1426. http://dx.doi.org/10.1016/j.applthermaleng.2005.05.030

Sugni M., Calcaterra E. y Adani F. (2005). Biostabilization-biodrying of municipal solid waste by inverting air-flow. Bioresource Technol. 96, 1331-1337. http:// dx.doi.org/10.1016/j.biortech.2004.11.016

Tambone F., Scaglia B. y Scotti S. (2011). Effects of biodrying process on municipal solid waste properties. Bioresource Technol. 102(16), 7443-7450. http:// dx.doi.org/10.1016/j.biortech.2011.05.010

Tremier A., de Guardia A., Massiani C., Paul E. y Martel J.L. (2005). A respirometric method for characterising the organic composition and biodegradation kinetics and the temperature influence on the biodegradation kinetics, for a mixture of sludge and bulking agent to be co-composted. Bioresource Technol. 96(2), 169180. http://dx.doi.org/10.1016/j.biortech.2004.05.005

Tiquia S.M. y Tam N.F. (2000). Fate of nitrogen during composting of chicken litter. Environ. Pollut. 110, 535541. http://dx.doi.org/10.1016/S0269-7491(99)00319-X

Velis C.A., Longhurst P.J., Drew G.H., Smith R. y Pollard S.T.J. (2009). Biodrying for mechanical-biological treatment of wastes: A review of process science and engineering. Bioresource Technol. 100, 2747-2761. http://dx.doi.org/10.1016/j.biortech.2008.12.026

Velis C.A., Longhurst P.J., Drew G.H., Smith R. y Pollard S.J.T. (2010). Production and quality assurance of solid recovered fuels using mechanical-biological treatment (MBT) of waste: a comprehensive assessment. Crit. Rev. Environ. Sci. Technol. 40(12), 979-1105. http:// dx.doi.org/10.1080/10643380802586980

Velis C.A., Wagland S., Longhurst P., Robson B., Sinfield K., Wise S. y Pollard S (2012). Solid Recovered Fuel: Influence of Waste Stream Composition and Processing on Chlorine Content and Fuel Quality. Environ. Sci. Technol. 46, 1923-1931. DOI: 10.1021/es2035653

Vuorinen A.H. (2000). Effect of the bulking agent on acid and alkaline phosphomonoesterase and b-D-glucosidase activities during manure composting. Bioresource 
Technol 75, 133-138. http://dx.doi.org/10.1016/S09608524(00)00042-0

Wagland S.T., Godley A.R. y Tyrrel S.F. y Smith R. (2009). Test methods to aid in the evaluation of the diversion of biodegradable municipal waste (BMW) from landfill. Waste Manage. 29(3), 1218-1226. http://dx.doi. org/10.1016/j.wasman.2008.08.024

Zhang D.Q., He P., Shao L., Jin T. y Han J. (2008). Biodrying of municipal solid waste with high water content by combined hydrolytic-aerobic technology. J. Environ. Sci. 20, 1534-1540.

DOI:10.1016/S1001-0742(08)62562-0
Zhang D., He P., Yu L.Z. y Shao L. (2009). Effect of inoculation time on the bio-drying performance of combined hydrolytic-aerobic process. Bioresource Technol. 100, 1087-1093. http://dx.doi.org/10.1016/j. biortech.2008.07.059

Zhao L., Gu W.M., He P.J. y Shao L.M. (2011). Biodegradation potential of bulking agents used in sludge bio-drying and their contribution to bio-generated heat. Water Res. 45, 2322-2330. http://dx.doi.org/10.1016/j. watres.2011.01.014 